\title{
Antioxidant enzyme activities in liver tissue of chickens fed diets supplemented with various forms and amounts of selenium*
}

\author{
K. Holovská Jr. ${ }^{1}$, K. Holovská ${ }^{2}$, K. Boldižárová ${ }^{1}$, S. Čekonová1, \\ V. Lenártová ${ }^{2}$, M. Levkut ${ }^{2}$, P. Javorský ${ }^{1}$ and L. Leng ${ }^{1,3}$ \\ ${ }^{1}$ Institute of Animal Physiology, Slovak Academy of Sciences \\ Šoltésovej 4, 04001 Košice, Slovak Republic \\ ${ }^{2}$ University of Veterinary Medicine \\ Komenského 73, 04001 Košice, Slovak Republic
}

(Received 3 July 2002; revised version 16 October 2002; accepted 20 December 2002)

\begin{abstract}
The effects of feed supplementation with anorganic and organic forms of Se on the activities of liver enzymes, glutathione peroxidase (cGPx) and superoxide dismutase (SOD), was examined in young growing chickens. The birds were divided to 4 groups on the day of hatching. The first group received the basic diet (BD) with a Se content $0.12 \mathrm{mg} \cdot \mathrm{kg}^{-1}$ of dry matter (DM) only. Diets for groups 2,3 and 4 consisted of BD supplemented with sodium selenite, $0.2 \mathrm{mg} \cdot \mathrm{kg}^{-1}$ of DM; Se-enriched yeast, 0.2 and $0.7 \mathrm{mg} \cdot \mathrm{kg}^{-1}$ of DM, respectively. Analysis of the liver tissue from 2- and 4-week-old chickens showed no effects of the various Se intake or effects of the form supplemented to the diet on cGPx activity. The 2-week-old birds showed no significant effects of diets on SOD activity in the liver tissue. On the other hand, liver SOD activity appeared to be dose-dependent in 4-week-old chickens, but no effects of the form of Se applied were found. Lipid peroxide formation measured as the appearance of thiobarbituric acid-reactive substances (TBARS) showed no dependence on the amount or form of Se supplemented to the ration, but its content in the liver of 4-week-old chickens was higher than in the 2-week-old ones. The selenium level in the liver tissue was clearly related to its contents in the feeds, but no effects of the form of selenium supplemented on this parameter were noticed after 2 or 4 weeks of dietary intake. The presented results suggest that dietary supplementation with Seyeast to a level reaching even $0.7 \mathrm{mg} \cdot \mathrm{kg}^{-1}$ of DM does not induce oxidative stress in young growing chickens. The synthesis of liver cGPx of 2- to 4- week-old chickens of a laying strain already seemed to be saturated at a dietary intake of Se at a level of $0.1 \mathrm{mg} \cdot \mathrm{kg}^{-1}$ of DM.
\end{abstract}

KEY WORDS: chicken, liver, selenium, glutathione peroxidase, superoxide dismutase

\footnotetext{
* Supported by the Grant Agency for Science, VEGA of Slovak Republic, Grant No 2/3066/23 and 2/3064/23

${ }^{3}$ Corresponding author: 1leng@saske.sk
} 


\section{INTRODUCTION}

Selenium (Se) is a nutritionally essential (Schwarz and Foltz, 1957) trace element. In animals several disorders related to selenium deficiency have been characterized, including muscular dystrophy (white muscle disease), liver necrosis, cardiac myopathy and exudative diathesis. All these syndromes appear to be essentially related to insufficient protection against oxidative stress (Wolffram, 1999).

Body Se is incorporated mainly into different kinds of selenoproteins having specific functions (Zachara 1993; Wolffram, 1999; Zagrodzki et al., 2001). Selenium exerts its best known biological role via the glutathione peroxidases (GPxs). The activity of this enzyme in the blood pGPx is frequently used as an indicator of Se status (Hafeman et al., 1974; Murray et al., 1987). The biochemical basis for Se deficiency in animals was explained by a discovery that the amino acid selenocysteine formed a structural component of the active center of cGPx (Rotruck et al., 1973). This enzyme provides a major defense mechanism against oxidative damage and accumulation of free radical products in tissues through the reduction of hydrogen peroxide, lipid hydroperoxides and other organic hydroperoxides (Tappel et al., 1982). Accordingly, inadequate levels of Se can lead to a reduction in cGPx activity and, consequently, to a decreased ability to degrade $\mathrm{H}_{2} \mathrm{O}_{2}$ (Kelly et al., 1998). Lipid peroxidation elevated by $32 \%$ was recently found in erythrocytes of Se-depleted chickens (Bozkaya et al., 2001). Deficient cGPx and increased $\mathrm{H}_{2} \mathrm{O}_{2}$ levels have both been linked to auto-oxidation of cell membranes, microtubular and DNA damage, impairment of immune cell function and bactericidal activity (Spielberg et al., 1979; McCallister et al., 1980). Thus, homeostatic regulation of optimal levels of Se appears critical for protecting tissues from $\mathrm{H}_{2} \mathrm{O}_{2}$-induced oxidative damage and for maintaining overall health.

From a nutritional point of view, the inorganic compounds selenate and selenite and the seleno-amino acids selenomethionine and selenocysteine are the most important chemical forms of selenium (Wolffram, 1999). The Se content of the plant components grown in Central Europe and used to complete the feeds for livestock does not exceed $0.1 \mathrm{mg} \cdot \mathrm{kg}^{-1}$ of dry matter (DM). Therefore selenium is widely added to feedstuffs in the form of sodium selenite to reach a final Se level from 0.3 to 0.5 mg.kg-1 of DM. Recently a trend to use organic forms of selenium supplements such as high Se-yeast (Falkowska et al., 2000) or seleninotriglycerides (Zagrodzki et al., 2000) in the feeds of farm animals instead of $\mathrm{Na}_{2} \mathrm{SeO}_{3}$ has appeared.

It is well established that selenide is a key product of the metabolism of both selenite and selenomethionine absorbed from the digestive tract (Schrauzer, 2000). Recently published results of Kobayashi et al. (2001) demonstrated that Se bound in the form of selenide to albumin is susceptible to oxidation, yielding selenite in vitro. These researchers suggested that this process might also occur in vivo. Selenite per se was shown to have considerable pro-oxidative features (Spallholz, 
1997). In other words, this means that any excessive intake of both anorganic and organic Se-compounds might result in increased production of reactive oxygen spieces with the relevant consequences.

This study investigated the effects of various dietary Se levels and its supplementation in the forms of sodium selenite or Se-yeast on the activities of the antioxidant enzyme cGPx and superoxide dismutase in the liver tissue. Concomitantly lipid peroxide formation and Se contents in the chicken liver were determined. The liver tissue was selected because it is known to have a considerable potential for a high rate of free radical generation due to its metabolic activities.

\section{MATERIAL AND METHODS}

\section{Animals, diets and treatment}

Forty eight female chickens of the laying strain Isa Brown were obtained on the day of hatching from LP-Párovské Háje a.s. (Slovak Republic). They were divided to 4 groups of 12 birds each and kept in large pens with wood shavings. From the first day of life until the age of four weeks the chickens were fed diets that differed either in total selenium content or only in the form of supplemented Se. The first group was given the basic diet (BD) with a Se content of 0.12 $\mathrm{mg} \cdot \mathrm{kg}^{-1}$ of dry matter (DM) coming only from the natural occurrence of Se in the dietary components. The diet for the second group of chickens was the same BD plus a Se supplement of $0.2 \mathrm{mg} \cdot \mathrm{kg}^{-1}$ of DM in the form of $\mathrm{Na}_{2} \mathrm{SeO}_{3}$ resulting in a final selenium level of $0.32 \mathrm{mg} \cdot \mathrm{kg}^{-1}$ of DM. The third group received a BD supplemented with $0.2 \mathrm{mg}$ of Se in the form of selenium yeast extract (Sel-Plex, Alltech, USA) yielding the same final Se level of $0.32 \mathrm{mg} \cdot \mathrm{kg}^{-1}$ as in the diet for the $2^{\text {nd }}$ group of birds. The diet for the $4^{\text {th }}$ group of chickens consisted of BD that was enriched with selenium $\left(0.7 \mathrm{mg} \cdot \mathrm{kg}^{-1}\right.$ of DM $)$ in the form of a Se-yeast extract (Sel-Plex, Alltech, USA) providing its total concentration of $0.82 \mathrm{mg} \cdot \mathrm{kg}^{-1}$. The diets for the $1^{\text {st }}, 2^{\text {nd }}$ and $3^{\text {rd }}$ groups were also fortified with adequate amounts of the yeast extract without Se (NUPRO, Alltech, USA) to obtain the same final levels of the yeast extract as in the $4^{\text {th }}$ diet $(63.7 \mathrm{~g}$ in $100 \mathrm{~kg}$ of feed). The mineral and vitamin premix for mixing into diets was supplied by Biotika a.s. (Slovak Republic). The final content of vitamin E in diets was $159 \mathrm{mg} \cdot \mathrm{kg}^{-1}$ of DM. The differences in the final contents of $\mathrm{Cu}$ and $\mathrm{Zn}$ in experimental diets caused by the additions of various amounts of Sel-Plex or NUPRO were less than $0.01 \%$ due to their minimal portion in diets. The final contents of $\mathrm{Cu}$ and $\mathrm{Zn}$ were 13.58 and $113.07 \mathrm{mg} \cdot \mathrm{kg}^{-1}$ of DM in feed for each group, respectively. The composition of $\mathrm{BD}$ is presented in Table 1 . 
The composition of the basic diet for chickens

\begin{tabular}{|c|c|}
\hline Component & $\%$ \\
\hline Maize ground $(9 \% \mathrm{CP})$ & 53.0 \\
\hline Solvent extracted soyabean meal $(3.5 \%$ crude fibre, $48 \% \mathrm{CP})$ & 23.0 \\
\hline Fish meal $(65 \% \mathrm{CP})$ & 4.0 \\
\hline Wheat, ground ( $11 \% \mathrm{CP})$ & 11.45 \\
\hline Premix BR 1 Forte $^{1}$ & 1.0 \\
\hline Dicalcium phosphate $(20 \% \mathrm{P})$ & 0.3 \\
\hline Salt & 0.25 \\
\hline Meat-and-bone meal with a middle contents of fat $(48 \% \mathrm{CP})$ & 5.0 \\
\hline Pulverised fat, BERGAFAT HPL 106 & 2.0 \\
\hline
\end{tabular}

${ }^{1}$ supplied per kg of diet: vit. A, $12500 \mathrm{IU}$; vit. $\mathrm{D}_{3}, 3500 \mathrm{ICU}$; vit. E, $150 \mathrm{mg}$; vit. $\mathrm{K}_{3}, 4 \mathrm{mg}$; thiamine, $3 \mathrm{mg}$; riboflavin, $9 \mathrm{mg}$; pyridoxine, $6 \mathrm{mg}$; cyanocobalamin, $40 \mu \mathrm{g}$; niacin, $60 \mathrm{mg}$; pantothenic acid, $15 \mathrm{mg}$; betaine, $277 \mathrm{mg}$; biotin, $0.2 \mathrm{mg}$; folic acid, $2 \mathrm{mg}$; L-lysine, $1.2 \mathrm{~g}$; DL-methionine, 1 g; I, 1 mg; Co, 0.4 mg; Mn, 100 mg, Cu, 8 mg; Zn, 80 mg; Fe, 80 mg

Chickens began to be reared with a lighting regimen of 23L:1D that was adjusted to $15 \mathrm{~L}: 9 \mathrm{D}$ after reaching three weeks of age. The initial room temperature $32-33^{\circ} \mathrm{C}$ was reduced every week by $3^{\circ} \mathrm{C}$ to a final temperature of $23^{\circ} \mathrm{C}$. All birds had free access to water and feed.

Six chickens from every group were slaughtered at the end of week 2 and 4 and their livers were collected and immediately frozen at $-24^{\circ} \mathrm{C}$.

\section{Sample analysis}

The tissue extractions of liver were washed two times with cooled physiological solution, cut into pieces, and homogenized in Ultra-Turrax T-25 homogenizer to make a $25 \%(\mathrm{w} / \mathrm{v})$ homogenate in $5 \mathrm{mM}$ Tris- $\mathrm{HCl}$ buffer, $\mathrm{pH} 7.8$ containing 0.15 $\mathrm{M} \mathrm{KCl}, 1 \mathrm{mM}$ EDTA, and $2 \mathrm{mM} \mathrm{GSH}$. Homogenates were centrifuged $60 \mathrm{~min}$ at $105,000 \mathrm{x}$ g using a Beckman L8-60 ultracentrifuge, and were stored at $-50^{\circ} \mathrm{C}$ until use for later assays. All procedures were performed at $4^{\circ} \mathrm{C}$.

Superoxide dismutase (E.C. 1.15.1.1; SOD) was measured according to Flohé and Ötting (1984), at $550 \mathrm{~nm}\left(25^{\circ} \mathrm{C}\right)$, through the inhibition of cytochrome c reduction using a xantine-xantine oxidase $\mathrm{O}_{2}$ generating system. One unit of SOD was defined as the amount of enzyme that inhibits the rate of cytochrome c reduction by $50 \%$, under the specified conditions.

Glutathione peroxidase (E.C. 1.11.1.9; cGPx) was measured according to Flohé and Günzler (1984) in a coupled assay with glutathione reductase using cumene hydroperoxide $\left(37^{\circ} \mathrm{C}, 340 \mathrm{~nm}\right)$. Enzyme activities are expressed in $\mathrm{U} / \mathrm{mg}$ of protein.

Lipid peroxide formation was measured as the appearance of malondialdehyde and other aldehydes by reaction with thiobarbituric acid yielding coloured products called 
thiobarbituric acid reactive substances (TBARS) that absorb at $535 \mathrm{~nm}$ (Gutteridge, 1984). The content of TBARS was expressed as absorbance/mg of protein.

The selenium concentration in the liver tissue was analysed in triplicate by the fluorimetric method of Rodriguez et al. (1994) and expressed in $\mu \mathrm{mol}$ per $\mathrm{kg}$ of dry matter. The standard procedure of tissue drying in an oven at $105^{\circ} \mathrm{C}$ was used to determine the dry matter content of the liver.

The protein concentration was determined by the method of Bradford (1976), using bovine serum albumin as a standard.

All reagents, of the highest purity, were from Sigma, Merck and Boehringer.

\section{Statistical procedure}

Statistical analysis was done by one-way analysis of variance (ANOVA) with the post hoc Tukey multiple comparisons test. The results are quoted as means $\pm \mathrm{SEM}$.

\section{RESULTS}

The measured selenium content in the liver tissue is depicted on Figure 1. The feeding of the diet with the basic level of Se (group 1) resulted in the significantly lowest liver Se concentration, while the diet supplemented with Se in yeast extract, $0.7 \mathrm{mg} \cdot \mathrm{kg}^{-1}$ (group 4) yielded the highest values in both 2- and 4-week-old chickens.

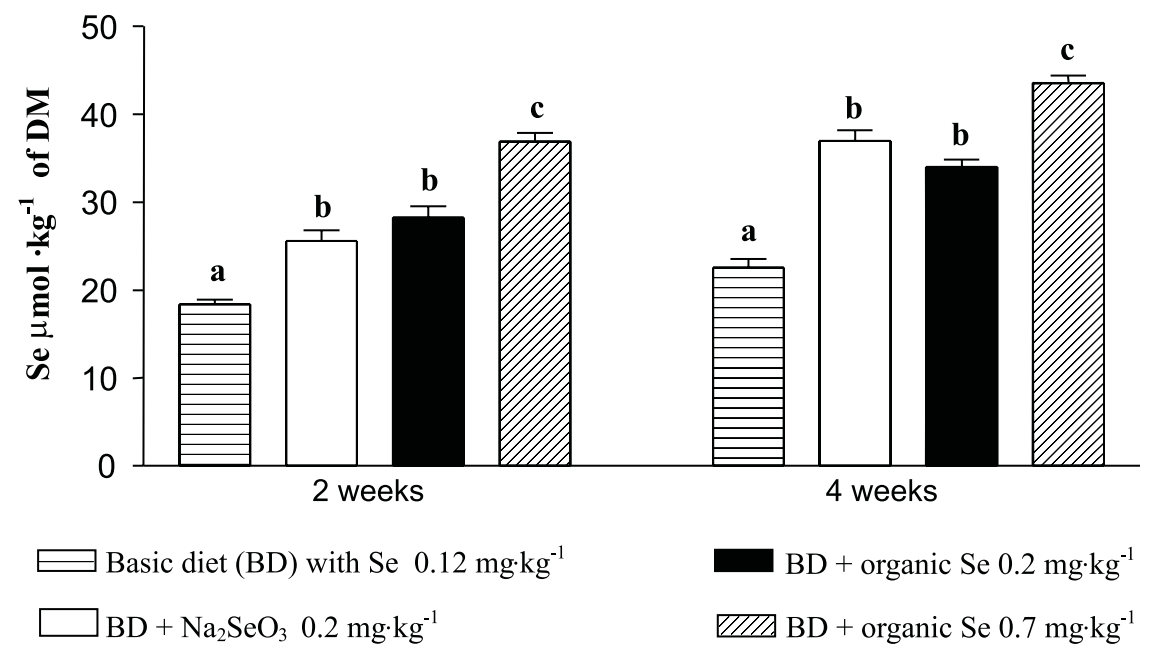

Figure 1 . The selenium concentration in the liver tissue (in $\mu \mathrm{mol} \cdot \mathrm{kg}^{-1}$ of dry matter) of chickens aged 2 and 4 weeks which were fed diets supplemented with anorganic $\left(\mathrm{Na}_{2} \mathrm{SeO}_{3}\right)$ or organic forms (Se-yeast) of Se. Values are means \pm SEM. Different letters above the column $=$ significant differences $(\mathrm{P}<0.05)$ 
The dose response was evident during the whole experiment. No differences in Se tissue levels due to the addition of the same amounts of anorganic (group 2) or organic forms of Se ( $3^{\text {rd }}$ group) could be observed in this short experiment. The liver selenium contents tended to increase with the age of the birds, but it was significantly elevated in group 2 only.

Though selenocysteine is a structural component of the active centre of glutathione peroxidase (cGPx), the activity of this enzyme was not found to be directly related to the tissue level of selenium (Figure 2). No effects of the Se forms used to supplement the feeds could be detected in the activities of this selenoenzyme. With the exception of group 2 fed a diet with an anorganic selenium supplement, a time response resulting in a significantly higher specific cGPx activity in 4-weekold chickens than in the 2-week-old ones was observed.

The activities of liver superoxide dismutase showed no differences between diets in 2-week- old chickens. On the other hand, the enzyme activity appeared to be dose dependent in 4-week-old chickens, but no effects of the form of Se applied could be found.

The appearance of thiobarbituric acid reactive substances (TBARS) in the liver significantly increased with age but no response to the amount or form of supplemented Se was found.

\section{DISCUSSION}

Studies on a number of species demonstrated that cGPx activity was directly related to blood and tissue Se concentration and to its dietary intake (Oh et al., 1976; Yoshida et al., 1999). Similarly, Behne et al. (1988) found that selenium content and glutathione peroxidase activity in the blood decrease rapidly during selenium depletion. Plasma and erythrocyte values are generally considered indicators of an inadequate selenium intake but not of the actual degree of deficiency or the levels of the element in most tissues. According to Wolffram (1999), a good correlation between tissue accumulation of selenium, e.g. in muscle or liver and the activity of cGPx exists in a situation of deficient or marginal selenium supply, whereas the correlation clearly weakens with nutritionally adequate selenium intake.

One of the possible explanations for a poor response of liver tissue cGPx to Se intake in our experiment appears that only a small proportion of Se received from feed was incorporated into cGPx. The other possibility was that animals already received a sufficient amount of Se from the basic diet ( $1^{\text {st }}$ group) to satisfy the $\mathrm{Se}$ requirement for synthesis of cGPx. Zachara et al. (1993) observed that the enzyme activity in the plasma of lambs fed a diet with $0.25 \mathrm{ppm}$ Se was almost at the same level as in higher Se-supplemented groups. This indicated that the Se requirement of lambs for different organs and tissues can be met by a daily dose of approximately 

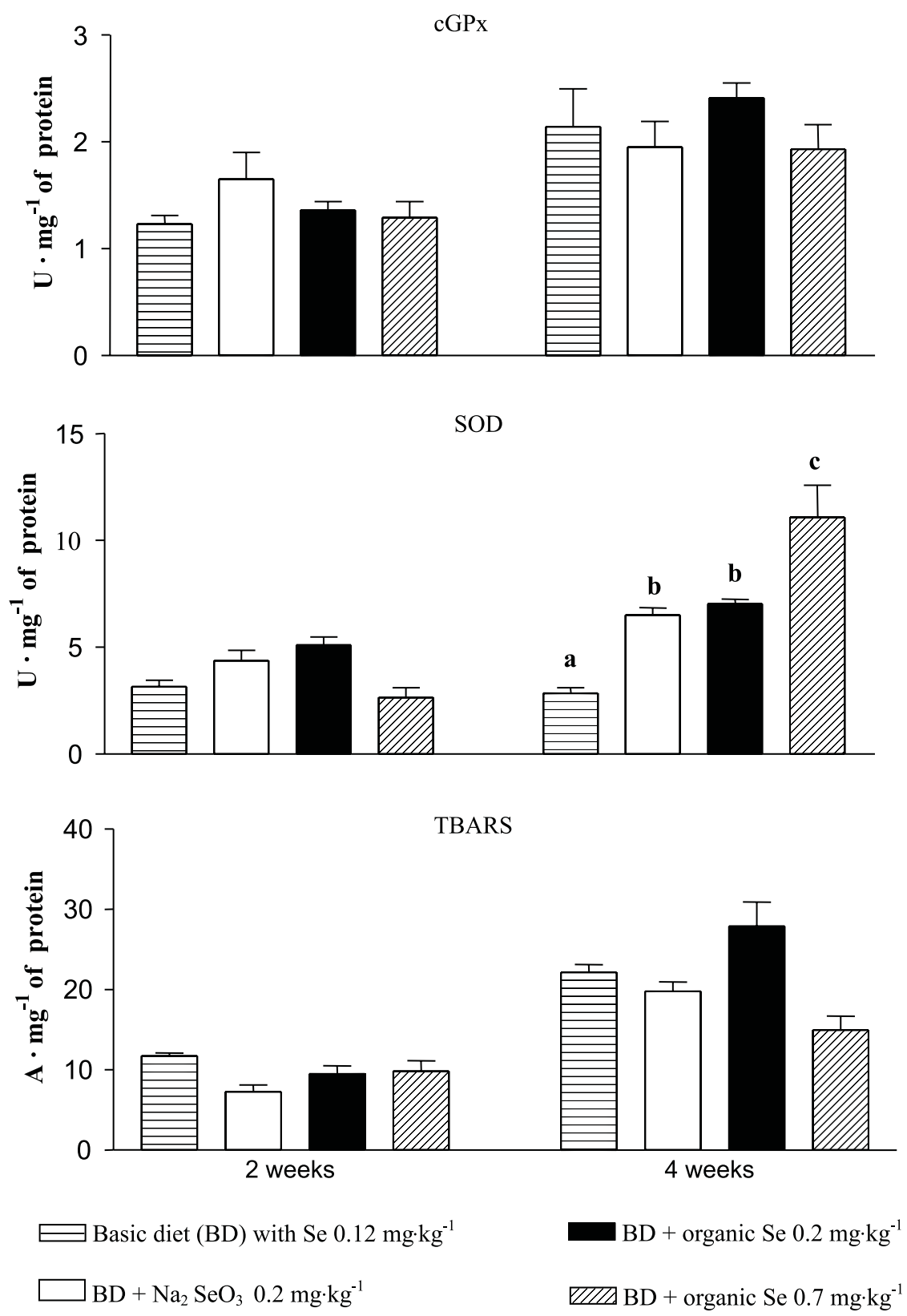

Figure 2. The activities of glutathione peroxidase (cGPx), superoxide dismutase (SOD) and the content of thiobarbituric acid reactive substances (TBARS) in the liver tissue of chickens aged 2 and 4 weeks. Birds were fed from the day of hatching the diets supplemented with anorganic $\left(\mathrm{Na}_{2} \mathrm{SeO}_{3}\right)$ or organic forms (Se-yeast) of selenium. Values are means \pm SEM. Different letters above the column $=$ significant differences $(\mathrm{P}<0.05) . \mathrm{A}=$ absorbance, $\mathrm{U}=$ units 
$0.25 \mathrm{ppm}$. The idea that selenium transferred by eggs from mothers (Paton et al., 2002) influenced the measured values of cGPx too could be excluded because the differences in liver Se contents due to its various intake were significant even in two-week-old chickens. Likewise Hafeman et al. (1974) investigated the dietary selenium effect on liver and erythrocyte cGPx in rats. They suggested that a level of $0.1 \mathrm{ppm}$ Se appeared to have met this requirement since increasing dietary Se from 0.1 to 0.5 or $1 \mathrm{ppm}$ induced only very small increases in cGPx.

The relatively narrow range between the beneficial effects of selenium and selenium toxicity is well known. Concentrations of 0.1 to $0.5 \mathrm{ppm}$ on a dry matter basis are generally accepted as safe and adequate for livestock and poultry (Oldfield, 1992; Edmondson et al., 1993). It is known that toxicity of Se is based on the production of the superoxide anion and other ROS which result in increased levels of lipid peroxidation and DNA strand breaks (Kitahara et al., 1993; Yan and Spallholz, 1993). This might be an explanation for our findings that the diet with the highest Se supplement (group 4) also induced the largest SOD activity in liver tissue. As can be seen from Figure 2, SOD activity was significantly increased in all three groups of chickens fed Se-supplemented diets for 4 weeks (groups 2, 3 and 4) compared with the birds kept on the diet with the basic Se content only (group 1).

The changes in these enzyme activities led us to study whether the larger dietary intake of Se could evoke oxidative stress. We analyzed malondialdehyde and other lipid peroxidation products by determining the levels of thiobarbituric acid reactive substances in liver tissue. There was no significant response to the amount of Se supplemented to diet.

The main reason for a using organic sources of selenium in chicken nutrition is based on the higher bioavailability of Se-methionine, the main Se-compound of Se-yeast (Schrauzer, 2000). We have recently shown that selenium from Seyeast, which was not used in the synthesis of specific selenoproteins, could escape reduction processes by its incorporation directly into the muscle protein of chicken (Čekonová et al., 2001). The creation of Se-methionine deposits in muscle tissue would not yield as much selenide in the circulation and, in turn, this would also mean lower production of pro-oxidative selenite. Finally, the evident good health of chickens in every group supported the idea that oxidative stress was not evoked in our experiment.

In conclusion, data from this experiment show that dietary supplementation with Se-yeast to a level reaching even $0.7 \mathrm{mg} \cdot \mathrm{kg}^{-1}$ does not induce oxidative stress in young growing chickens. The dietary intake of Se already at a level of $0.1 \mathrm{mg} \cdot \mathrm{kg}^{-1}$ of DM seems to saturate the requirements of 2- to 4-week-old chickens of a laying strain for the synthesis of liver cGPx. 


\section{REFERENCES}

Behne D., Hilmert H., Scheid S., Gessner H., Elger W., 1988. Evidence for specific selenium target tissues and new biologically important selenoproteins. Biochem. Biophys. Acta 966, 12-21

Bozkaya L.A., Öztürk-Ürek R., Aydemir T., Tarhan L., 2001. Effects of Se, Cu a and Se + vitamin E deficiency on the activities of CuZnSOD, GSH-Px, CAT and LPO levels in chicken erythrocytes. Cell Biochem. Function 19, 153-157

Bradford M.M., 1976. A rapid and sensitive method for the quantification of microgram quantities of protein utilizing the principle of protein-dye binding. Anal. Biochem. 72, 248-254

Čekonová S., Grešáková L., Boldižárová K., Levkutová M., Ševčíková Z., Révajová V., Levkut M., Leng L', 2001. The activity of glutathione peroxidase in a blood of chicks fed diet with various contents and forms of selenium. In: Proceedings of $6^{\text {th }}$ Conference on Immunocytochemistry and Clinical Pathology in Veterinary Medicine, Košice (Slovak Republic), pp. 41-44

Edmondson A.J., Norman B.B., Suther D., 1993. Survey of state veterinarians and state veterinary diagnostics laboratories for selenium deficiency and toxicosis in animals. J. Amer. Vet. Med. Assoc. 202, 865-874

Falkowska A., Minakowski D., Tywończuk J., 2000. The effect of supplementing rations with selenium and vitamin $\mathrm{E}$ on biochemical parameters in blood and performance of cows in the early stage of lactation. J. Anim. Feed Sci. 9, 271-282

Flohé L., Günzler W.A., 1984. Assays of glutathione peroxidase. Methods Enzymol. 105, 114-121

Flohé L., Ötting, F., 1984. Superoxide dismutase assays. Methods Enzymol. 105, 93-104

Gutteridge J.M.C., 1984. Ferrous ion-EDTA-stimulated phospholipid peroxidation. Biochem. J. 224, 697-701

Hafeman D.G., Sunde R.A., Hoekstra W.G., 1974. Effect of dietary selenium on erythrocyte and liver glutathione peroxidase in the rat. J. Nutr. 104, 580-587

Kelly S.A., Havrilla C.M., Brady T.C., Abramo K.H., Levin E.D., 1998. Oxidative stress in toxicology: Established mammalian and emerging piscine model systems. Environ. Health Perspect. 106, 375-384

Kitahara J., Seko Y., Imura N., 1993. Possible involvement of active oxygen species in selenite toxicity in isolated rat hepatocytes. Arch. Toxicol. 67, 497-501

Kobayashi Y., Ogra Y., Suzuki K.T., 2001. Speciation and metabolism of selenium injected with ${ }^{82} \mathrm{Se}-$ enriched selenite and selenate in rats. J. Chromatogr. B 760, 73-81

McCallister J., Harris R.E., Baehner P.L., Boxer L.A., 1980. Alteration of microtubule function in glutathione peroxidase-deficient polymorphonuclear leukocytes. J. Reticuloendothelial Soc. 27, 59-66

McMurray C.H., Davidson W.B., Blanchflower W.J., 1987. The distribution of selenium in the tissues of lambs following intramuscular administration of different levels of sodium selenite. Brit. Vet. J. 143, 51-58

Oh S.H., Sunde R.A., Pope A.L., Hoekstra W.G., 1976. Glutathione peroxidase response to selenium intake in lambs fed torula yeast-based artificial milk. J. Anim. Sci. 42, 977-983

Oldfield J.E., 1992. Risks and benefits in agricultural uses of selenium. Environm. Geochem. Health $14,81-86$

Paton N.D., Cantor A.H., Pescatore A., Ford M.J., Smith C.A., 2002. Absorption of selenium by developing chick embryos during incubation. In: T.P. Lyons, K.A. Jacques (Editors). Nutritional Biotechnology in the Feed and Food Industry. Nottingham University Press, Nottingham, pp. 10-121

Rodriguez E.M., Sanz M.T., Romero C.D., 1994. Critical study of fluorimetric determination of selenium in urine. Talanta 12, 2025-2031

Rotruck J.T., Pope A.L. Ganther H.E. Swanson A.B., Hafeman D.G., Hoekstra W.G., 1973. Selenium: Biochemical role as a component of glutathione peroxidase. Science 179, 588-590

Schrauzer G.N., 2000. Selenomethionine: A review of its nutritional significance, metabolism and toxicity. J. Nutr. 130, 1653-1656 
Schwarz K., Foltz C.M., 1957. Selenium as an integral part of factor-3 against necrotic liver degeneration. J. Amer. Chem. Soc. 79, 3292-3293

Spallholz J.E., 1997. Free radical generetion by selenium compounds and their prooxidant toxicity. Biomed. Environ. Sci.10, 260-270

Spielberg S.P., Boxer L.A., Oliver J.M., Allen J.M., Schulman J.D., 1979. Oxidative damage to neutrophils in glutathione synthetase deficiency. Brit. J. Hematol. 42, 215-223

Schwarz K., Foltz C.H., 1957. Selenium as an integral part of factor 3 against dietary liver degeneration. J. Amer. Chem. Soc. 79, 3292-3293

Tappel M.E., Chaudiere J., Tappel A.L., 1982. Glutathione peroxidase activities of animal tissues. Comp. Biochem. Physiol. 73B, 945-949

Wolffram S., 1999. Absorption and metabolism of selenium: differences between inorganic and organic sources. In: T.P. Lyons, K.A. Jacques (Editors). Biotechnology in the Feed Industry. Nottingham University Press, Nottingham, pp. 547-566

Yan L., Spallholz J.E., 1993. Generation of reactive oxygen species from the reaction of selenium compounds with thiols and mammary tumor cells. Biochem. Pharmacol. 45, 429-437

Yoshida M., Fukunaga K., Tsuchita H., Yasumoto K., 1999. An evaluation of the biovailability of selenium in high-selenium yeast. J. Nutr. Sci. Vitaminol. 45, 119-128

Zachara B.A., Trafikowska U., Labedzka H., Mikolajczak J., 1993. Effect of dietary Se intake on blood Se levels and glutathione peroxidase activities in lambs. Small Ruminant Res. 9, 331-340

Zagrodzki P., Bik D., Fitak B.A., Suchocki P., Niemczuk K., 2000. Selenoenzymes in animal tissues after supplementation with selol. Bull. Vet. Inst. Pulawy 44, 215-220

Zagrodzki P., Nicol F., Arthur J.R., Slowiaczek M., 2001. Selenoproteins in human thyroid tissues. BioFactors 14, 223-227

\section{STRESZCZENIE}

\section{Aktywność enzymów antyoksydacyjnych w tkance wątrobowej kurcząt żywionych dietami uzupełnionymi różnymi związkami i różną ilością selenu}

Badano wpływ dodatku nieorganicznych i organicznych związków Se na aktywność enzymów wątroby: peroksydazy glutationowej (cGpx) oraz tlenku dysmutazy (SOD) u rosnących kurcząt brojlerów. Ptaki podzielono na 4 grupy w dniu wylęgu. Pierwsza grupa otrzymywała dietę kontrolną (BD) zawierającą $0,12 \mathrm{mg} \cdot \mathrm{kg}^{-1} \mathrm{Se}$ w s.m. Diety 2, 3 i 4 składały się z diety kontrolnej uzupełnionej (w s.m.): seleninem sodu, $0,2 \mathrm{mg} \cdot \mathrm{kg}^{-1}$, drożdżami wzbogaconymi w Se: 0,2 i $0,7 \mathrm{mg} \cdot \mathrm{kg}$, odpowiednio.

Nie stwierdzono wpływu ani rodzaju ani ilości Se na aktywność cGPx w tkance wątrobowej kurcząt 2-i 4-ro tygodniowych, a także na aktywność SOD u kurcząt 2-tygodniowych. Aktywność SOD u kurcząt 4-ro tygodniowych wydaje się jednak być zależna od ilości Se, a nie od jego formy. Powstawanie peroksydazy lipidowej mierzone pojawieniem się reaktywnych związków kwasu triobarbiturowego (TBARS) nie zależało ani od ilości ani od formy dodatku Se, lecz jej zawartość w wątrobie 4-ro tygodniowych kurcząt była większa niż u 2-tygodniowych. Poziom Se w tkance wątrobowej wyraźnie zależał od jego zawartości w paszy, natomiast rodzaj związków nie miał na to wpływu u 2- i 4-ro tygodniowych kurcząt.

Otrzymane wyniki wskazują, że uzupełnienie dawki drożdżami wzbogaconymi w Se w ilość $0,7 \mathrm{mg} \cdot \mathrm{kg}^{-1} \mathrm{~s} . \mathrm{m}$. nie wywołuje stresu tlenowego u młodych rosnących kurcząt. Synteza wątrobowej cGPx u kurcząt 2-i 4-ro tygodniowych linii kur nieśnych wydaje się osiągać nasycenie już przy dziennym pobraniu Se w ilości $0,1 \mathrm{mg} \cdot \mathrm{kg}^{-1} \mathrm{~s} . \mathrm{m}$. 